\title{
Five Years Later: An Update on the Status of Collections of Endemic Gulf of Mexico Fishes Put at Risk by the 2010 Oil Spill
}

\author{
Prosanta Chakrabarty ${ }^{\ddagger}$, , Glynn A. O’Neill', Brannon Hardy', Brandon Ballengee \\ ‡ Louisiana State Unviersity Museum of Natural Science, Baton Rouge, Louisiana, United States of America \\ $\S$ National Science Foundation, Arlington, Virginia, United States of America \\ | Louisiana State University, Baton Rouge, United States of America \\ I Louisiana State Unviersity Museum of Natural Science, Baton Rouge, United States of America
}

\section{Corresponding author: Prosanta Chakrabarty (prosanta@lsu.edu)}

Academic editor: Pavel Stoev

Received: 04 Apr 2016 | Accepted: 11 Aug 2016 | Published: 18 Aug 2016

Citation: Chakrabarty P, O’Neill G, Hardy B, Ballengee B (2016) Five Years Later: An Update on the Status of

Collections of Endemic Gulf of Mexico Fishes Put at Risk by the 2010 Oil Spill. Biodiversity Data Journal 4: e8728. doi: $\underline{10.3897 / B D J .4 . e 8728}$

\begin{abstract}
\section{Background}

The 2010 Gulf of Mexico Oil Spill took place over 180,000 square kilometers during a 12week period over five years ago; however, this event continues to influence the development and distribution of organisms in and around the region of the disaster. Here we examine fish species that may have been most affected by noting their past distribution in the region of the spill and examining data of known collecting events over the last 10 years (five years prior to the spill, five years post spill).
\end{abstract}

\section{New information}

We found that more than half of the endemic fish species of the Gulf (45 of 77 ) 


\section{Keywords}

BP, Deepwater Horizon, Macondo, ichthyology, fish

\section{Introduction}

The 2010 Gulf of Mexico Oil Spill (also called the Deepwater Horizon/BP disaster/oil spill, or Macondo blowout among others) was the largest accidental spill of oil in history (Crone and Tolstoy 2010, Rabalais 2014). Coupled with the fact that it occurred in the deep sea (>1000 $\mathrm{m}$ depth) and with the coordinated release of more than a million gallons of dispersant, it is one of the greatest pollution events in history (Goodbody-Gringley et al. 2013). The long lasting effects of the spill are still not fully understood even five years after the event. There is considerable evidence that some species continue to be physically and developmentally challenged by the impact of the spill, particularly fishes (Whitehead et al. 2011; Incardona et al. 2014; Dubansky et al. 2013; Brette et al. 2014; Mager et al. 2014; Alloy et al. 2016). However, population studies of fishes remain poorly examined (Fodrie et al. 2014). Although, fisheries for commercial species are better studied, the ichthyofauna as a whole has received little attention. Chakrabarty et al. (2012) listed fish species in need of conservation concern based on their known distribution in relation to the historical surface position of the oil spill. Here we reexamine the distribution of all 77 known endemic Gulf fish species five years after the spill based on collection records (as a reminder endemic means in this context, species only found in the Gulf of Mexico). We compare these post-spill records with those from five years prior to the spill.

These collection records are obtained from natural history museum records of specimen collections. Museum collections are a vital source for biological records (Drew 2011; Rocha et al. 2014). They maintain a record of the world's biodiversity by keeping specimens recorded from a certain area and time allowing comparisons to be made across time and space. With these collections one can compare a changing fauna before and after a catastrophic event, such as an oil spill. The correct identification of specimens is also vital (Chakrabarty et al. 2013), as museum collections are maintained by taxonomists and the specimens and comparative material are at hand, the identifications from these collections are more trustworthy than those from ship records or other sources where specimens are discarded. Here we use these collection records to examine the affects of the 2010 Gulf of Mexico Oil Spill on the endemic fishes of the region. 


\section{Methods and Results}

The occurrence records of the 77 endemic species of the Gulf of Mexico were tallied using The Global Biodiversity Information Facility and FishNet2 from October-December of 2015. Duplicate events from the two databases were deleted (duplicates were discovered if they had the same museum catalog numbers). A scatter plot graph was then created in Microsoft Excel showing collections five years prior to the 2010 Oil Spill and five years post spill. Only collections records from the Gulf of Mexico were counted (assuming for these endemics that records from outside the region are likely misidentifications).

Scatter plots of endemic fishes from the Gulf of Mexico are shown below with the "Number of Occurrence(s)" on the y-axis vs. the "Number of Years" on the x-axis. Species are listed in alphabetical order. Endemic species that have few or no collections records do not have a scatterplot but details about their last collecting events are presented. The scientific name is also presented followed by common name (when there is one) and family. Spill zone overlap information is from Chakrabarty et al. (2012). If the scientific name has changed in the past five years we show both the old and new names. Conservation information about "Resilience" is taken from FishBase (Froese and Pauly 2016). Resilience is based upon the time it takes to double the species population and are as follows: Very Low (minimum of 14 years to double population); Low (4.5-14 years to double population); Medium (1.4-4.4 years to double population); High (less than 15 months to double population).

1) Alosa alabamae - Alabama Shad - Clupeidae (1\% range overlap with spill zone). Resilience: Medium (Fig. 1)

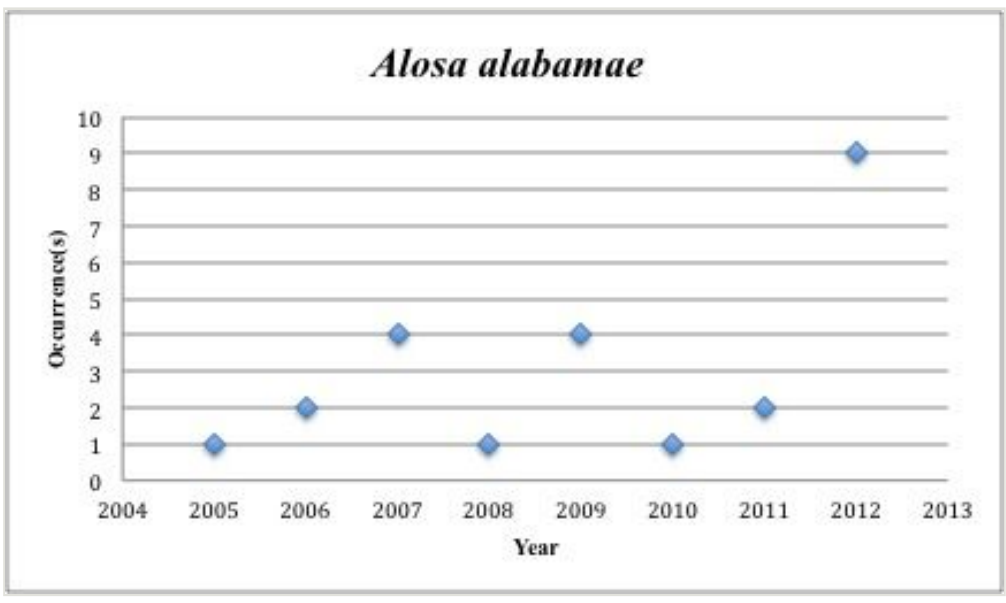

Figure 1.

Alosa alabamae

2) Alosa chrysochloris - Skipjack Shad - Clupeidae (2\% range overlap with spill zone). Resilience: Medium (Fig. 2) 


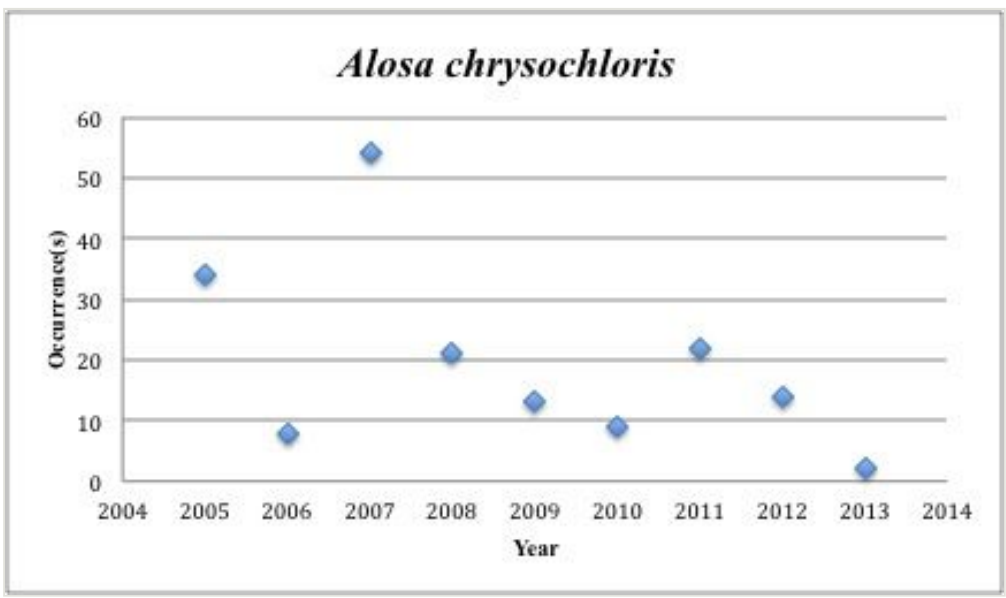

Figure 2.

Alosa chrysochloris

3) Anacanthobatis folirostris - Leaf-nose Leg Skate - Anacanthobatidae (79\% range overlap with spill zone). Resilience: Low. - last time collected: 2004

4) Atherinella schultzi - Chimalapa Silverside - Atherinopsidae (No range overlap with spill zone). Resilience: High - collected once (2013) since 2005

5) Atractosteus spatula - Alligator Gar - Lepisosteidae (No range overlap with spill zone). Resilience: Very low (Fig. 3)

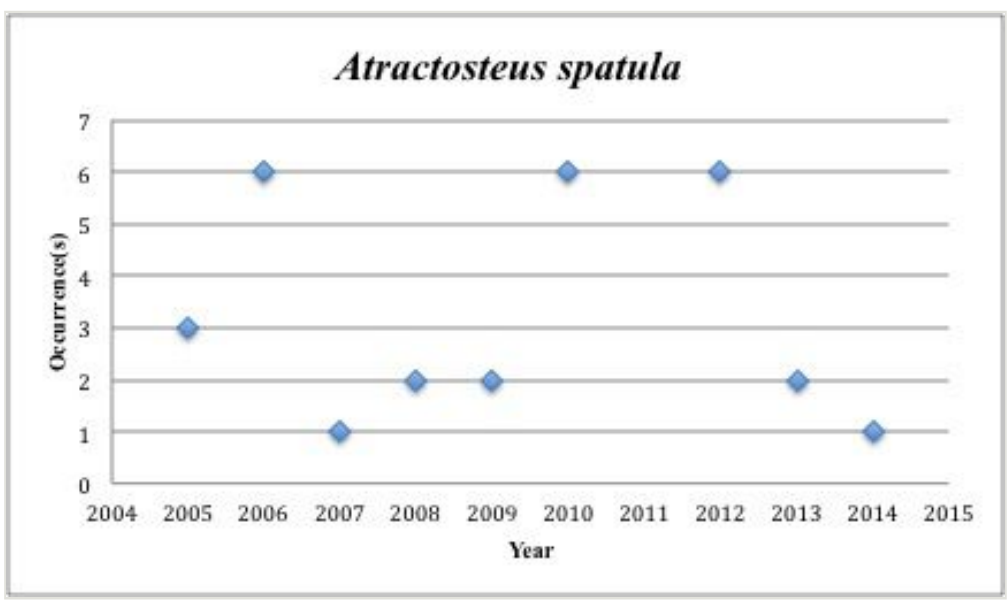

Figure 3.

Atractosteus spatula 
6) Bollmannia communis - Ragged Goby - Gobiidae (41\% range overlap with spill zone). Resilience: High (Fig. 4)

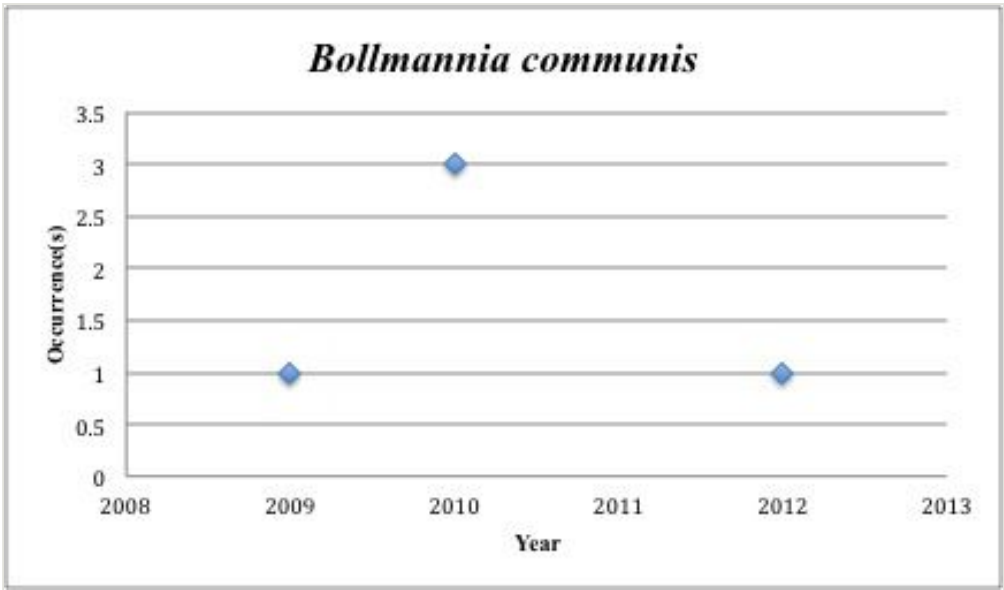

Figure 4.

Bollmannia communis

7) Bollmannia eigenmanni - Shelf Goby - Gobiidae (64\% range overlap with spill zone). Resilience: Medium - last time collected: 1988

8) Brevoortia gunteri - Finescale Menhaden - Clupeidae (2\% range overlap with spill zone). Resilience: Medium (Fig. 5)

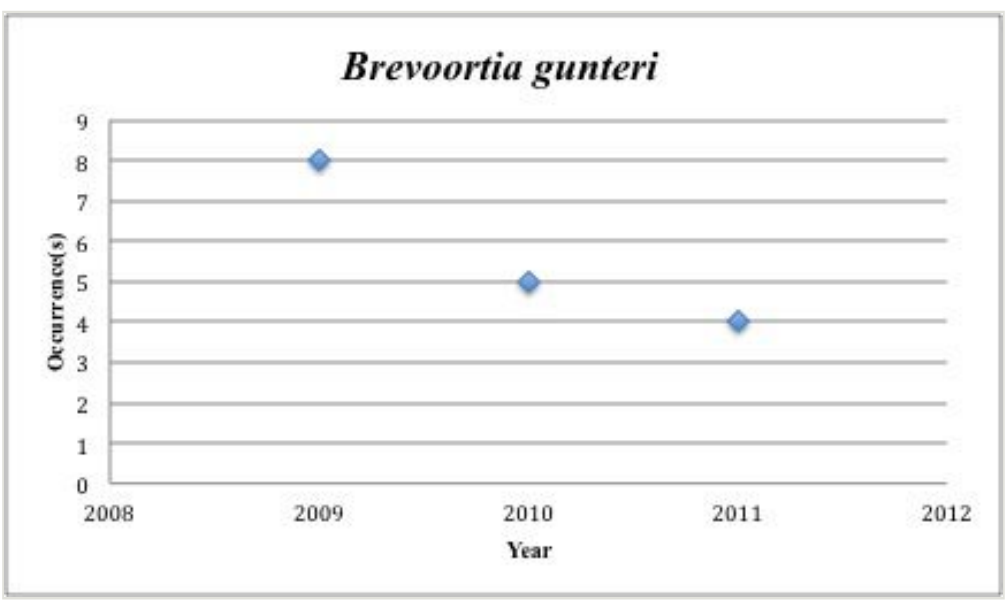

Figure 5.

Brevoortia gunteri 
9) Brevoortia patronus - Gulf Menhaden - Clupeidae (11\% range overlap with spill zone). Resilience: Medium (Fig. 6)

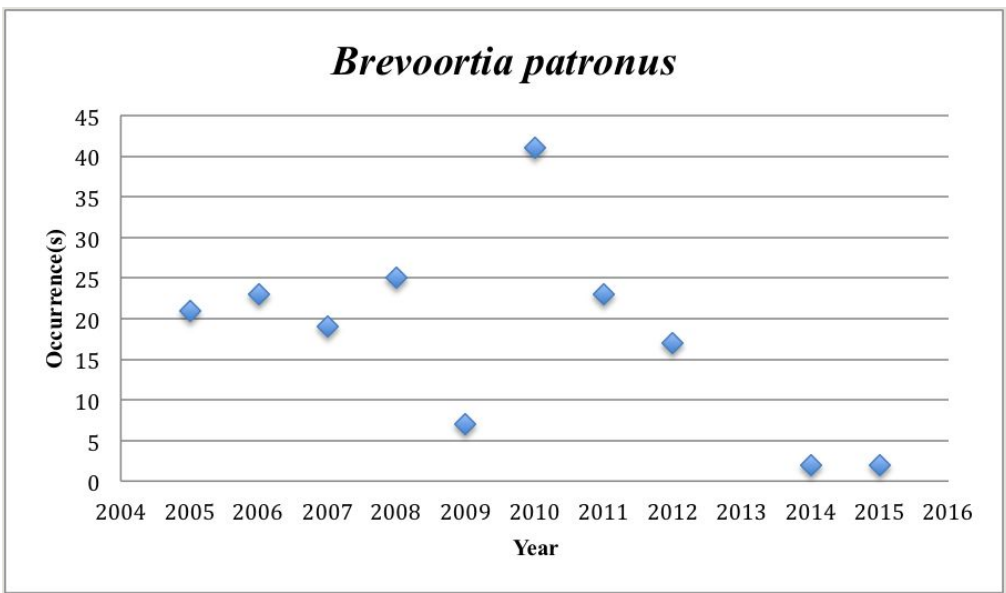

Figure 6.

Brevoortia patronus

10) Calamus arctifrons - Grass Porgy - Sparidae (No range overlap with spill zone). Resilience: Medium (Fig. 7)

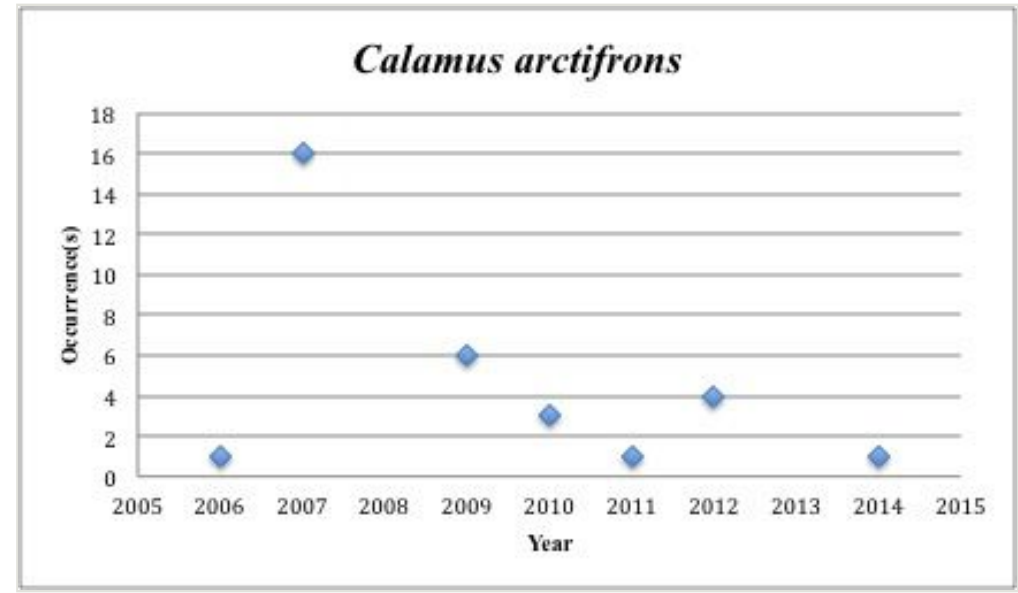

Figure 7.

Calamus arctifrons 
11) Calamus campechanus - Campeche Porgy - Sparidae (No range overlap with spill zone). Resilience: Medium - last time collected: 1987

12) Chasmodes longimaxilla - Stretchjaw Blenny - Blenniidae (No range overlap with spill zone). Resilience: High - last time collected: 1983

13) Chriolepis benthonis - Deepwater Goby - Gobiidae (No range overlap with spill zone). Resilience: High - last time collected: 1953

14) Chriolepis vespa - Wasp Goby - Gobiidae (No range overlap with spill zone). Resilience: High - last time collected: 1970

15) Citharichthys abbotti - Veracruz Whiff - Paralichthyidae (No range overlap with spill zone). Resilience: High - last time collected: 2001

16) Coryphaenoides mexicanus - Mexican Grenadier - Macrouridae (54\% range overlap with spill zone). Resilience: Medium (Fig. 8)

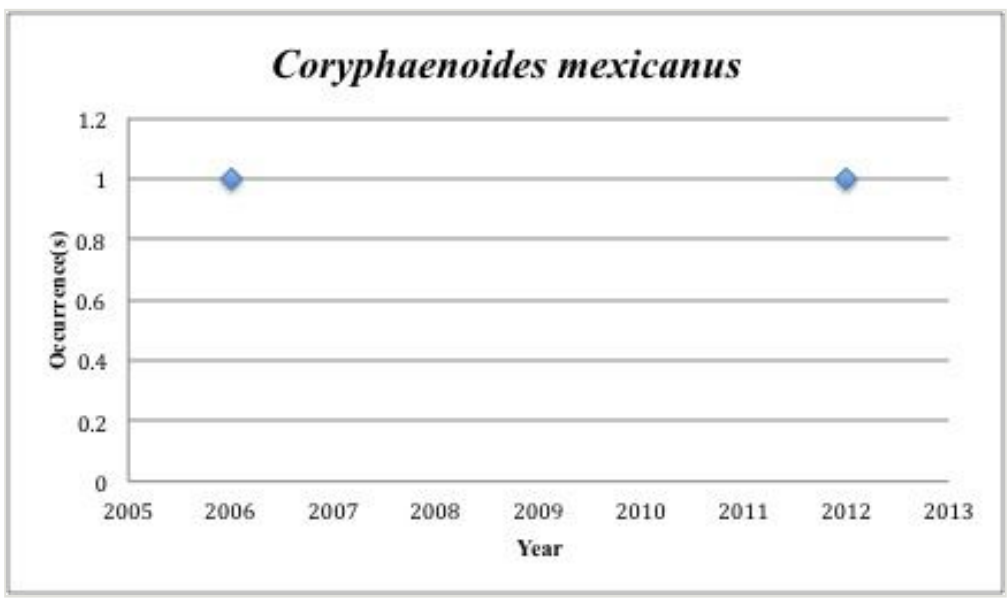

Figure 8.

Coryphaenoides mexicanus

17) Coryphopterus punctipectophorus - Spotted Goby - Gobiidae (No range overlap with spill zone). Resilience: High - last time collected: 1982

18) Ctenogobius claytonii - Mexican Goby - Gobiidae (No range overlap with spill zone). Resilience: High - collected once (2005) since 2005

19) Cynoscion arenarius - Sand Weakfish - Sciaenidae (12\% range overlap with spill zone). Resilience: Medium (Fig. 9) 


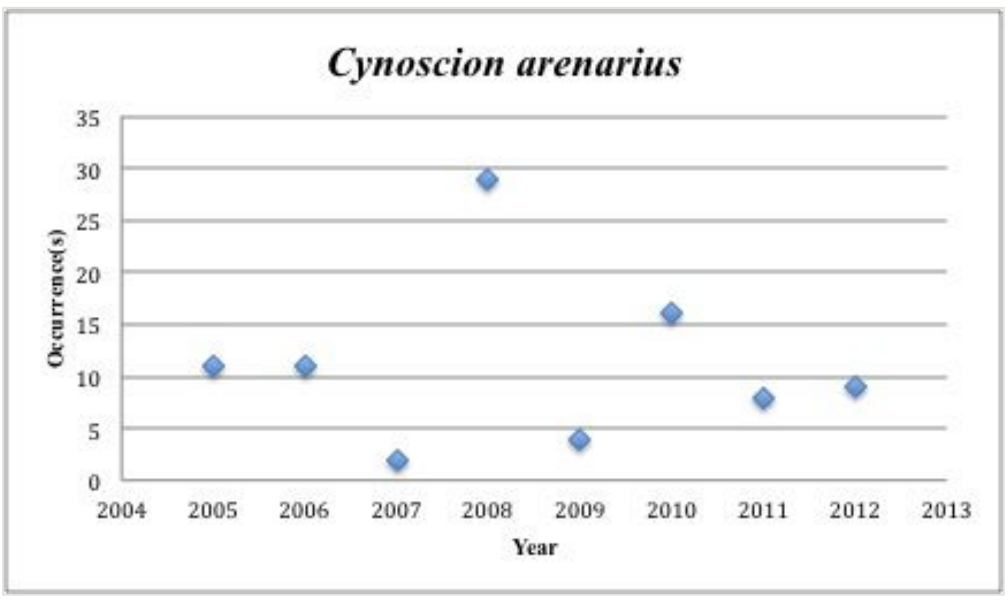

Figure 9.

Cynoscion arenarius

20) Dipturus olseni - Spreadfin Skate - Rajidae (29\% range overlap with spill zone). Resilience: Low - collected twice (2005) since 2005

21) Dipturus oregoni - Hooktail Skate - Rajidae ( $80 \%$ range overlap with spill zone). Resilience: Low - last time collected: 1987

22) Eptatretus minor - Hagfish - Myxinidae (23\% range overlap with spill zone). Resilience: Low - collected twice (2005) since 2005

23) Eptatretus springeri - Gulf hagfish - Myxinidae (54\% range overlap with spill zone). Resilience: Low - collected once (2010) since 2005

24) Etmopterus schultzi - Fringefin Lanternshark - Etmopteridae ( $90 \%$ range overlap with spill zone). Resilience: Low - collected five times (2006) since 2005

25) Eustomias leptobolus - Stomiidae (40\% range overlap with spill zone). Resilience: High - last time collected: 1960

26) Exechodontes daidaleus - Zoarcidae (No range overlap with spill zone). Resilience: High - last time collected: 1989

27) Floridichthys carpio - Goldspotted killifish - Cyprinodontidae (No range overlap with spill zone). Resilience: High (Fig. 10) 


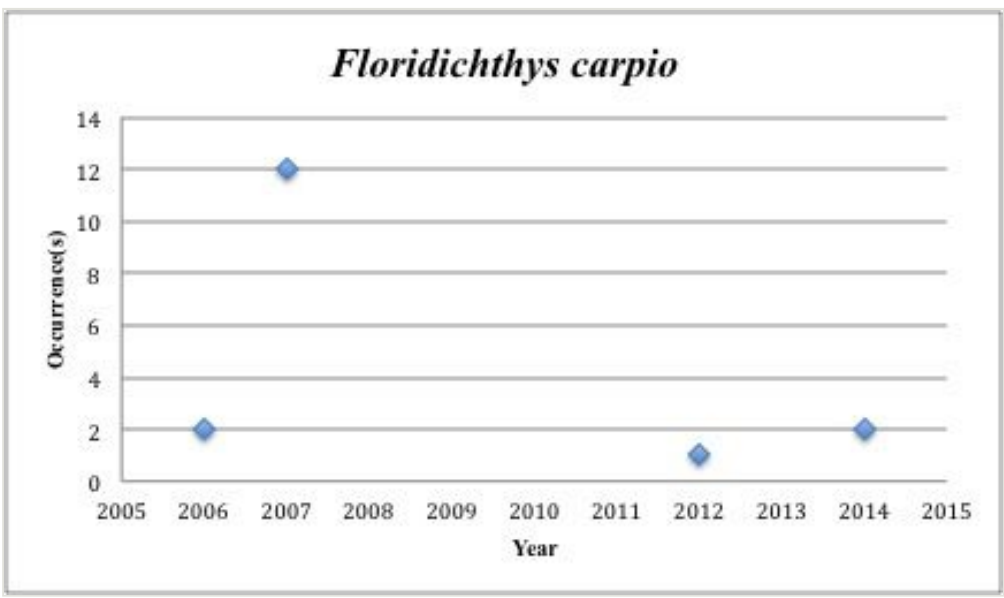

Figure 10.

Floridichthys carpio

28) Fundulus grandis - Gulf Killifish - Fundulidae (13\% range overlap with spill zone). Resilience: High (Fig. 11)

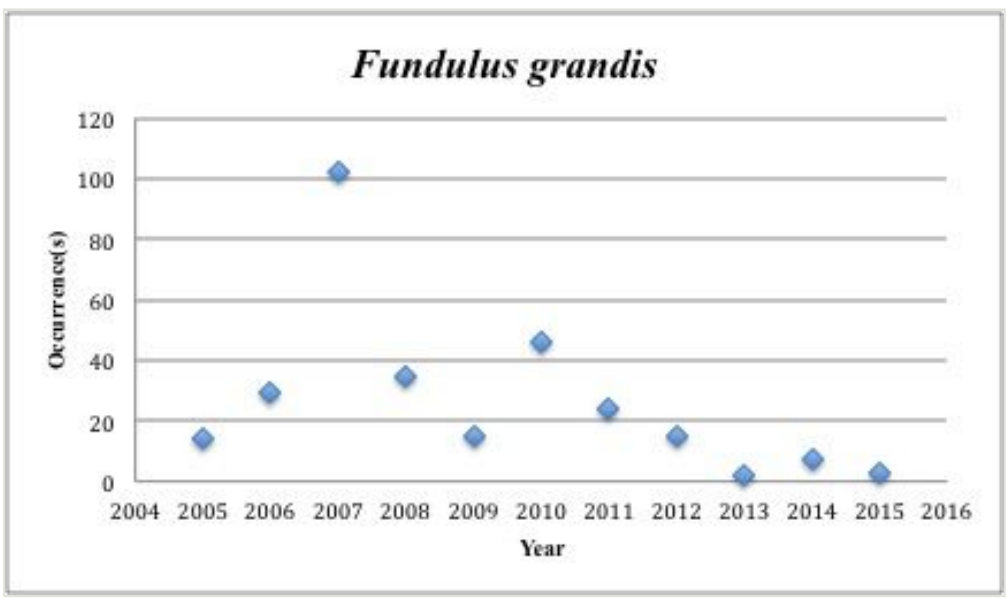

Figure 11.

Fundulus grandis

29) Fundulus jenkinsi - Saltmarsh Topminnow - Fundulidae (4\% range overlap with spill zone). Resilience: High (Fig. 12) 


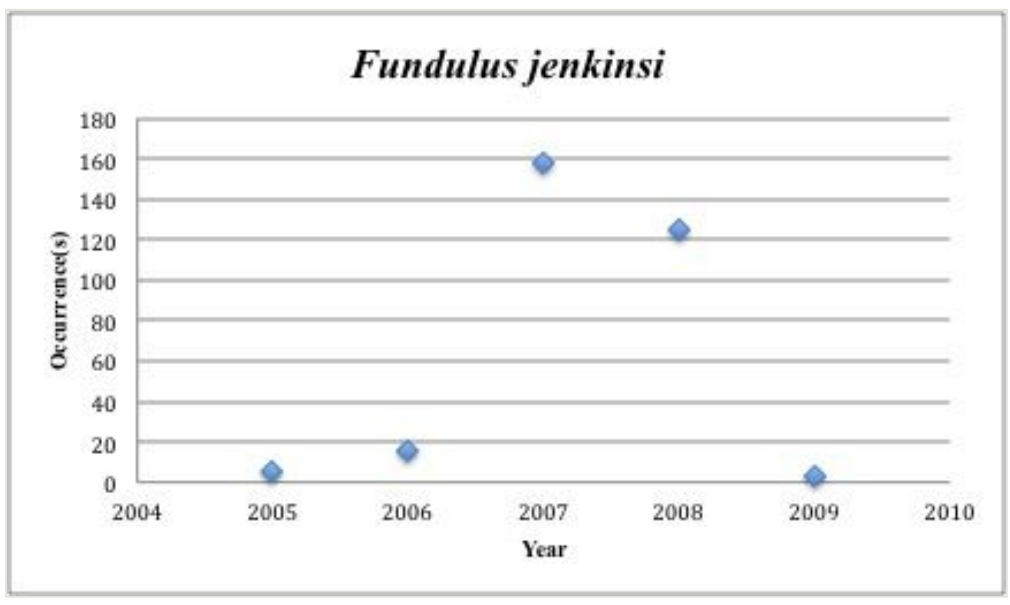

Figure 12.

Fundulus jenkinsi

30) Fundulus persimilis - Yucatán Killifish - Fundulidae (No range overlap with spill zone).

Resilience: High - collected twice in 2005

31) Fundulus pulvereus - Bayou Killifish - Fundulidae (18\% range overlap with spill zone).

Resilience: High (Fig. 13)

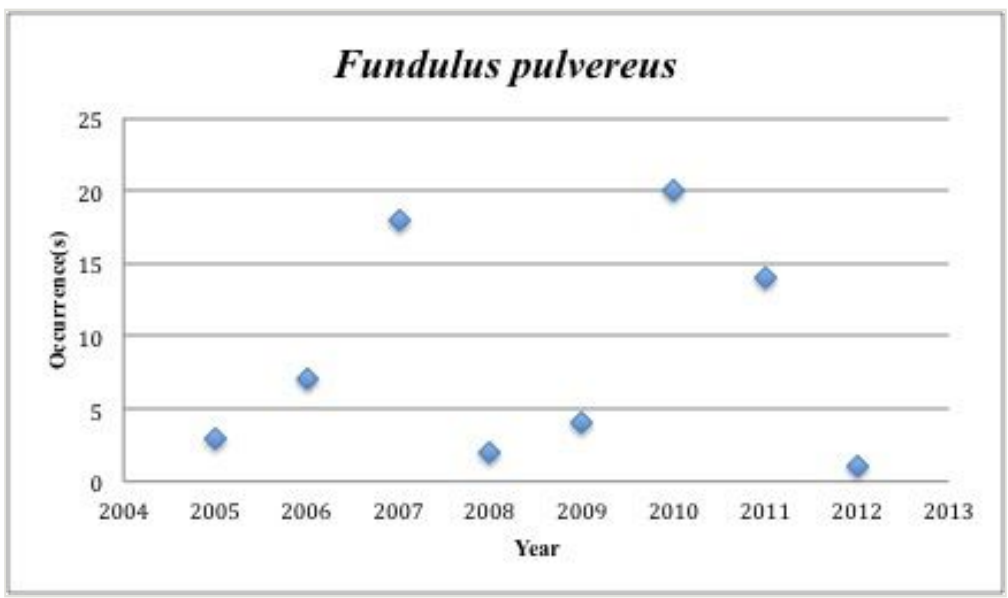

Figure 13.

Fundulus pulvereus

32) Fundulus xenicus (formerly Adinia xenica) - Diamond Killifish - Fundulidae (13\% range overlap with spill zone). Resilience: Low (Fig. 14) 


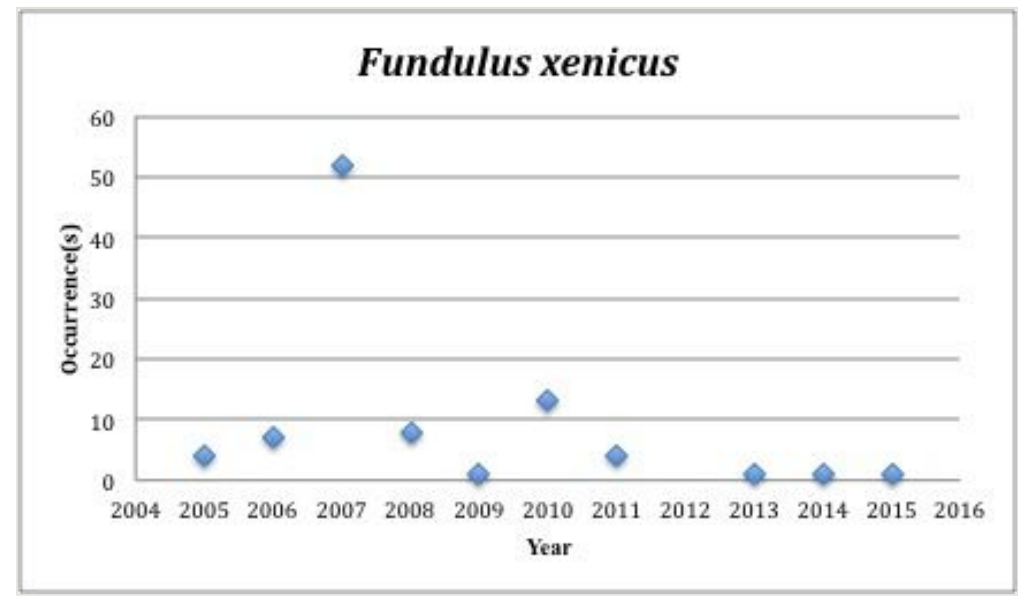

Figure 14.

Fundulus xenicus

33) Gambusia yucatana - Yucatan Mosquitofish - Poeciliidae (No range overlap with spill zone). Resilience: High (Fig. 15)

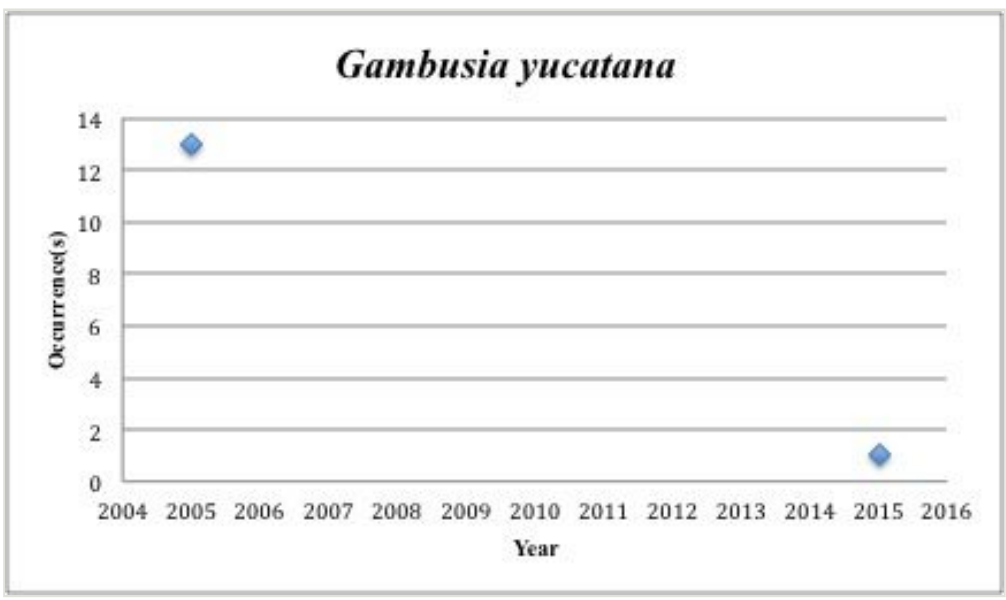

Figure 15.

Gambusia yucatana

34) Gobiosoma longipala - Twoscale Goby - Gobiidae (No range overlap with spill zone). Resilience: High - collected 2 times (2012) since 2005

35) Gordiichthys ergodes - Irksone Eel - Ophichthidae (No range overlap with spill zone).

Resilience: Medium (Fig. 16) 


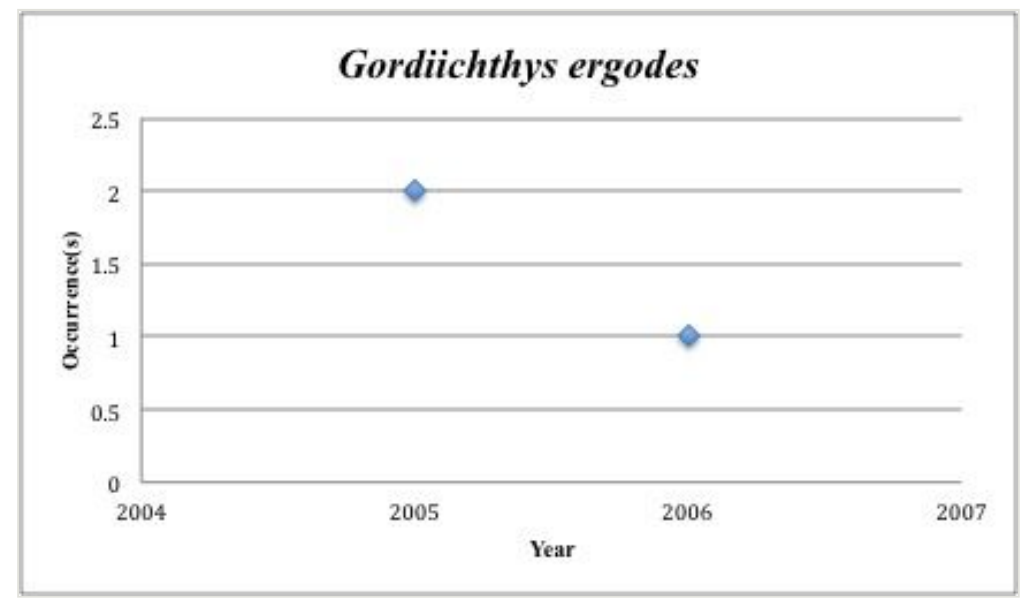

Figure 16.

Gordiichthys ergodes

36) Gordiichthys leibyi - String Eel - Ophichthidae (No range overlap with spill zone). Resilience: Medium - last time collected: 2004

37) Gunterichthys longipenis - Gold Brotula - Bythitidae (88\% range overlap with spill zone). Resilience: Low - last time collected: 2002

38) Gymnachirus texae - Gulf of Mexico Fringed Sole - Achiridae (16\% range overlap with spill zone). Resilience: High - collected once (2012) since 2005

39) Halichoeres burekae - Mardi Gras Wrasse - Labridae (No range overlap with spill zone). Resilience: High - collected twice (2006) since 2005

40) Halieutichthys intermedius - Louisiana Pancake Batfish - Ogcocephalidae (68\% range overlap with spill zone). Resilience: High - collected five times (2010) since 2005

41) Heteroconger luteolus - Yellow Garden Eel - Congridae (No range overlap with spill zone). Resilience: Medium - last time collected: 2004

42) Hyperoglyphe bythites - Black Driftfish - Centrolophidae (82\% range overlap with spill zone). Resilience: Medium - collected once (2008) since 2005

43) Hypleurochilus caudovittatus - Zebratail Blenny - Blenniidae (Insufficient data) Resilience: High - last time collected: 2004

44) Hypleurochilus multifilis - Featherduster Blenny - Blenniidae (25\% range overlap with spill zone). Resilience: High - last time collected: 2001

45) Ijimaia antillarum - Ateleopodidae (8\% range overlap with spill zone). Resilience: Unknown - last time collected: 2004 
46) Jordanella floridae - Flagfish - Cyprinodontidae (No range overlap with spill zone).

Resilience: Low (Fig. 17)

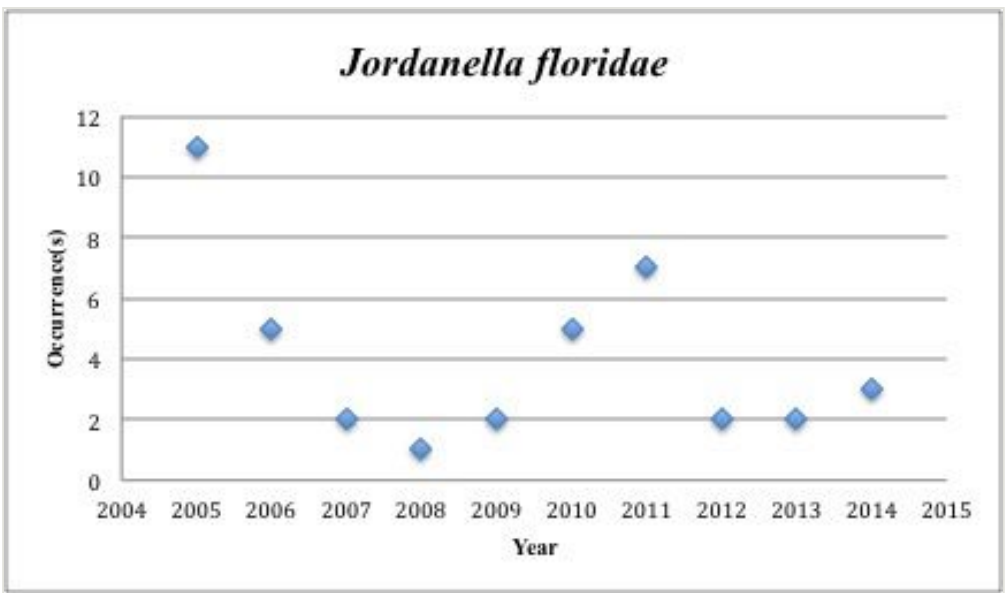

Figure 17.

Jordanella floridae

47) Jordanella pulchra (previously Garmanella pulchra) - Yucatán flagfish Cyprinodontidae (No range overlap with spill zone). Resilience: High - collected 10 times (2005) since 2005

48) Lepisosteus oculatus - Spotted Gar - Lepisosteidae (0.2\% range overlap with spill zone). Resilience: Medium (Fig. 18)

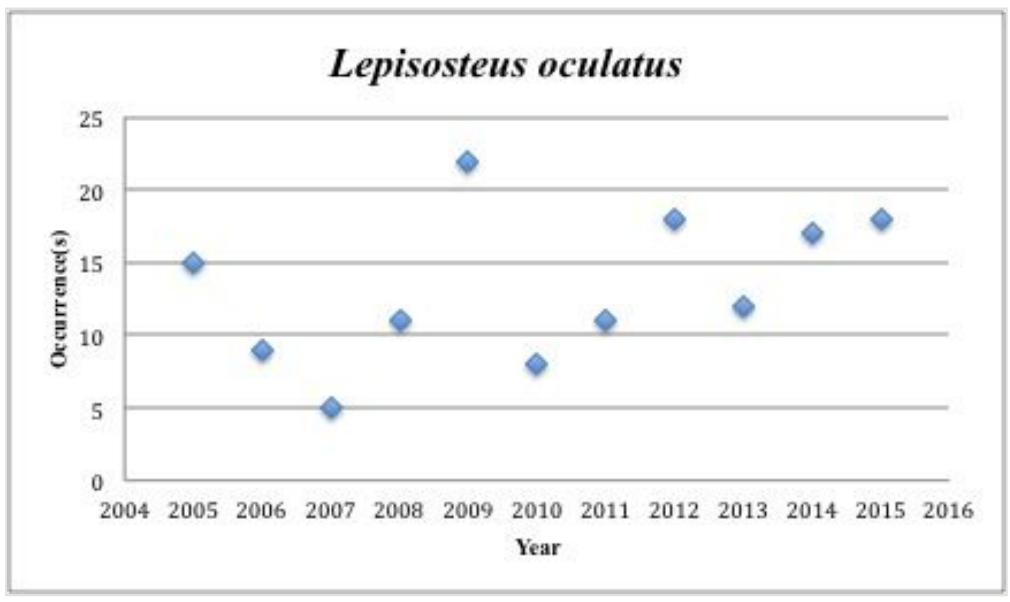

Figure 18.

Lepisosteus oculatus 
49) Leucoraja lentiginosa - Freckled Skate - Rajidae (53\% range overlap with spill zone).

Resilience: Low - collected once (2012) since 2005

50) Lupinoblennius nicholsi - Highfin Blenny - Blenniidae (No range overlap with spill zone). Resilience: High - last time collected: 2000

51) Lycenchelys bullisi - Zoarcidae (50\% range overlap with spill zone). Resilience: Medium - last time collected: 1999

52) Menidia clarkhubbsi - Texas Silverside - Atherinopsidae (No range overlap with spill zone). Resilience: High - last time collected: 2000

53) Menidia colei -Golden Silverside - Atherinopsidae (No range overlap with spill zone). Resilience: High - collected 29 times (2005) since 2005

54) Menidia conchorum - Key Silverside - Atherinopsidae (No range overlap with spill zone). Resilience: High - last time collected: 1978

55) Microdesmus lanceolatus - Lancetail Wormfish - Microdesmidae (43\% range overlap with spill zone). Resilience: High - last time collected: 1980

56) Monopenchelys acuta - Redface Moray - Muraenidae (No range overlap with spill zone). Resilience: High (Fig. 19)

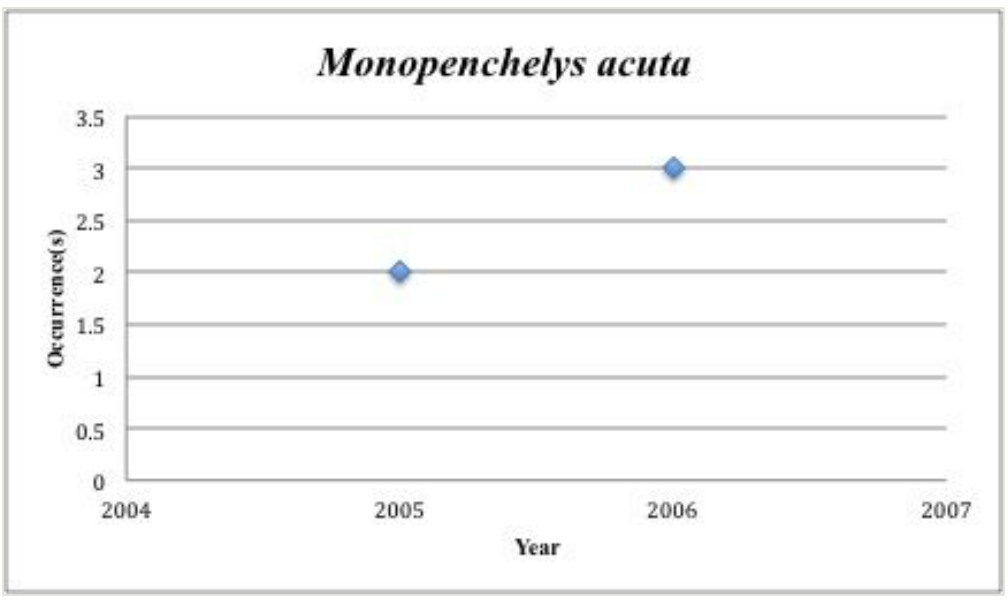

Figure 19.

Monopenchelys acuta

57) Mustelus sinusmexicanus - Gulf Smooth-hound - Triakidae (43\% range overlap with spill zone). Resilience: Low (Fig. 20) 


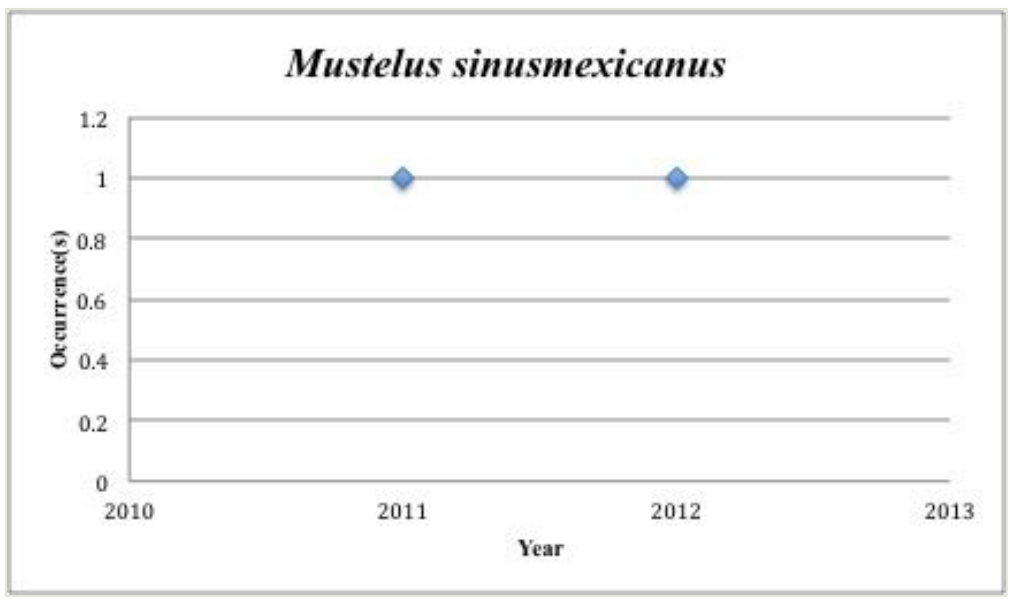

Figure 20.

Mustelus sinusmexicanus

58) Neoopisthopterus cubanus - Cuban Longfin Herring - Pristigasteridae (Insufficient data). Resilience: High - last time collected: N/A

59) Ogcocephalus pantostictus - Spotted Batfish -Ogcocephalidae (3\% range overlap with spill zone). Resilience: Low (Fig. 21)

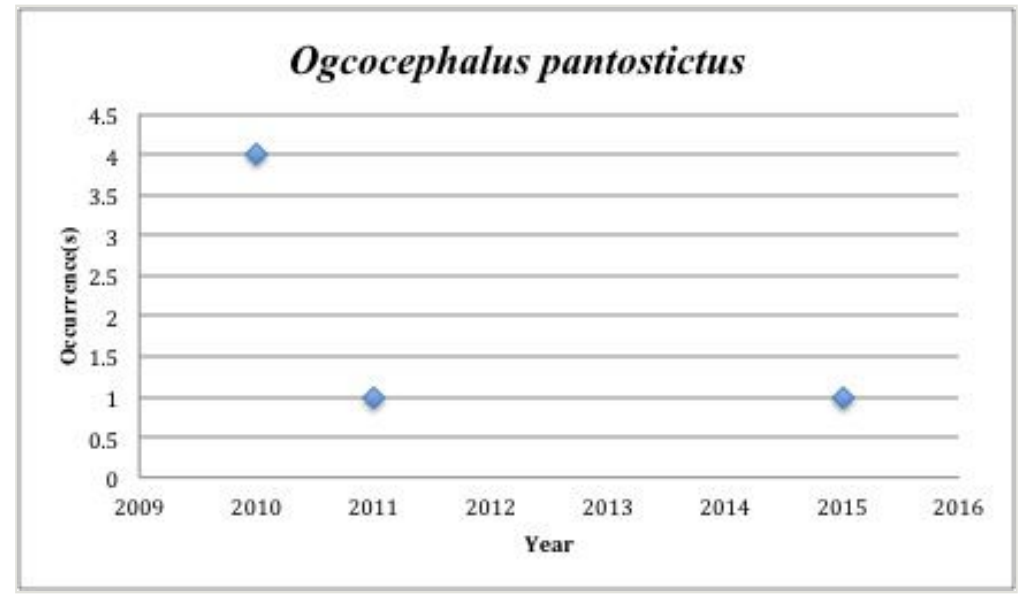

Figure 21.

Ogcocephalus pantostictus

60) Ogilbia cayorum - Key Brotula - Bythitidae (No range overlap with spill zone). Resilience: Low (Fig. 22) 


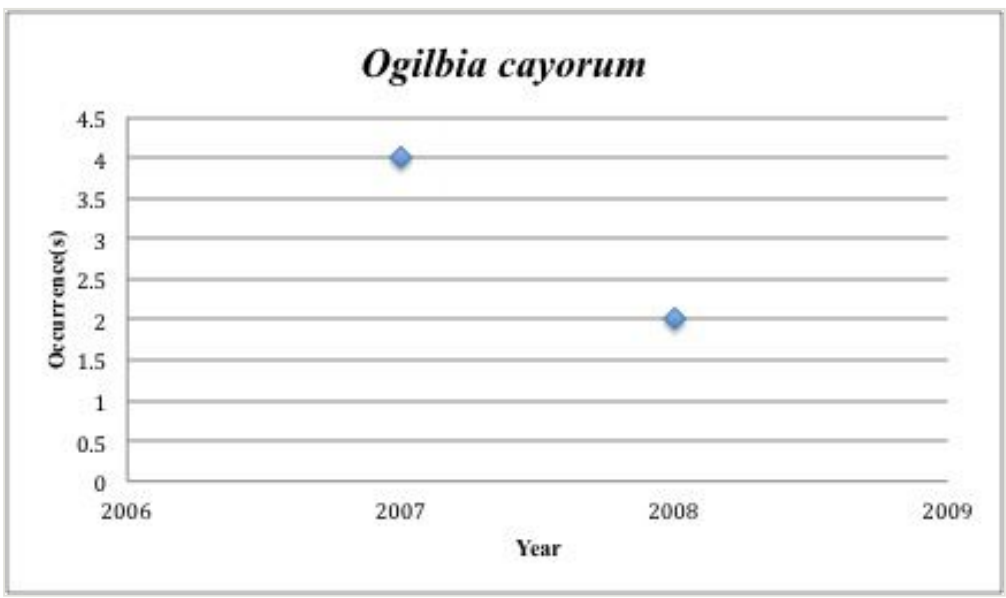

Figure 22.

Ogilbia cayorum

61) Oneirodes bradburyae - Oneirodidae (100\% range overlap with spill zone). Resilience: High - last time collected: 1954

62) Ophichthus omorgmus - Dotted Snake Eel - Ophichthidae (Insufficient data). Resilience: Medium - last time collected: 1999

63) Ophichthus rex - King Snake Eel - Ophichthidae (82\% range overlap with spill zone). Resilience: Very low - collected once (2009) since 2005

64) Opsanus pardus - Leopard Toadfish - Batrachoididae (38\% range overlap with spill zone). Resilience: Low (Fig. 23)

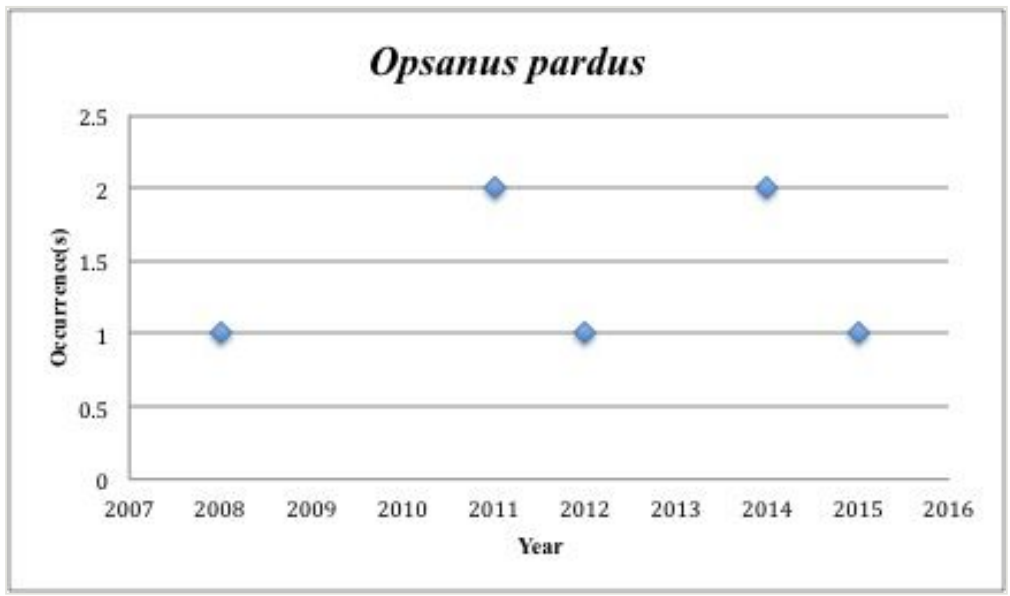

Figure 23.

Opsanus pardus 
65) Parasaccogaster rhamphidognatha (previously Saccogaster rhamphidognatha) (100\% range overlap with spill zone). Resilience: High - last time collected: N/A

66) Parmaturus campechiensis - Campeche Catshark - Pentanchidae (Insufficient data). Resilience: Low - last time collected: 1970

67) Prionotus longispinosus - Bigeye Sea Robin - Triglidae (50\% range overlap with spill zone). Resilience: Medium (Fig. 24)

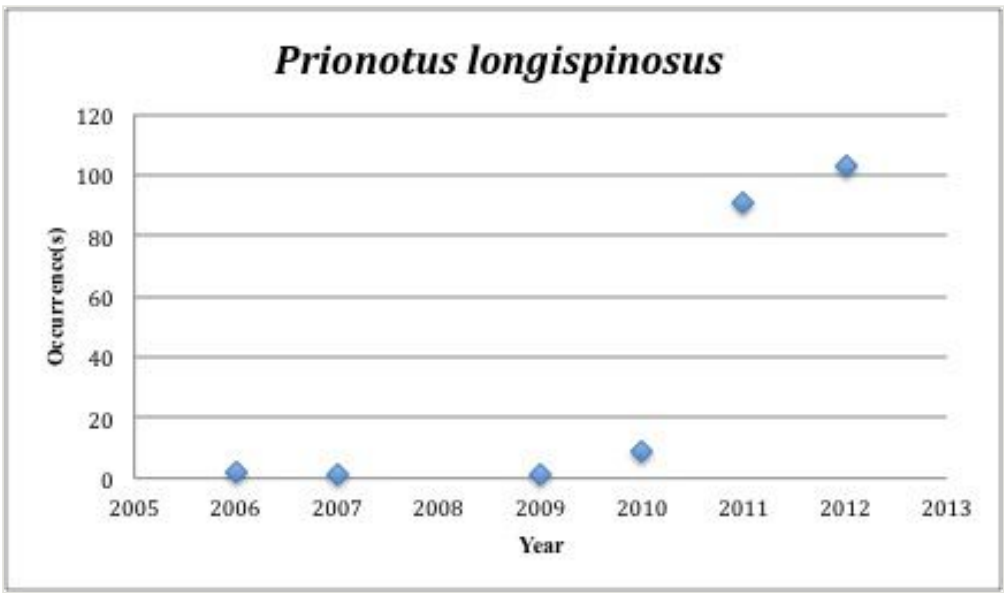

Figure 24.

Prionotus longispinosus

68) Prionotus martis - Gulf of Mexico Barred Sea Robin - Triglidae (5\% range overlap with spill zone). Resilience: High (Fig. 25)

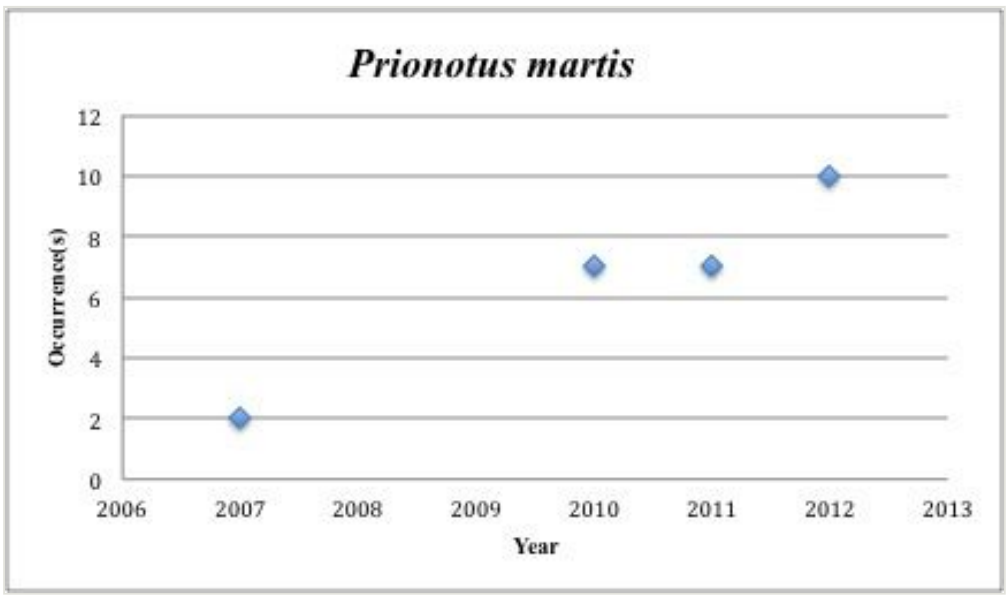

Figure 25.

Prionotus martis 
69) Prionotus paralatus - Mexican Sea Robin - Triglidae (Insufficient data). Resilience: High (Fig. 26)

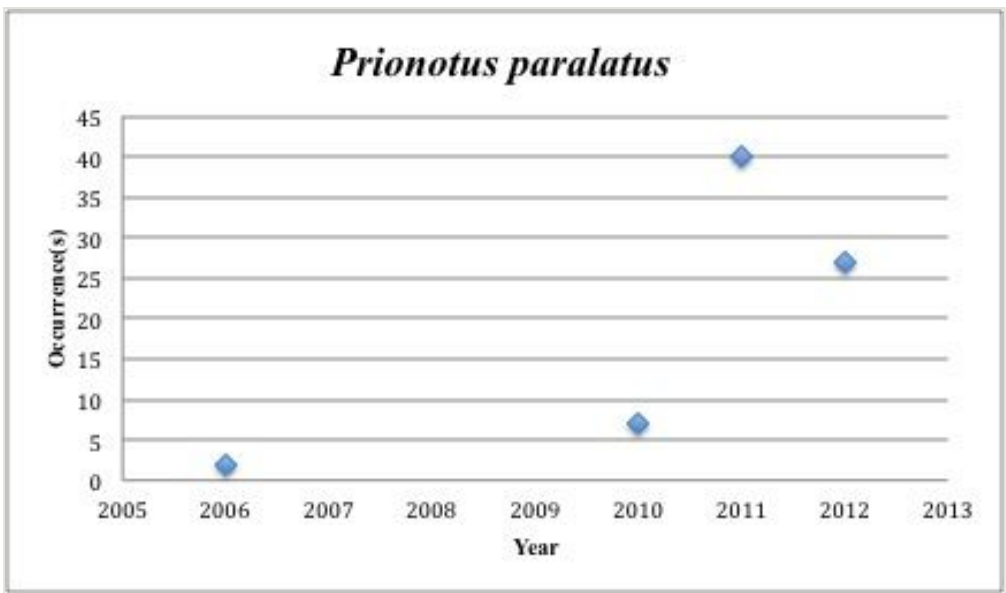

Figure 26.

Prionotus paralatus

70) Raja texana - Roundel Skate - Rajidae (11\% range overlap with spill zone). Resilience: Low (Fig. 27)

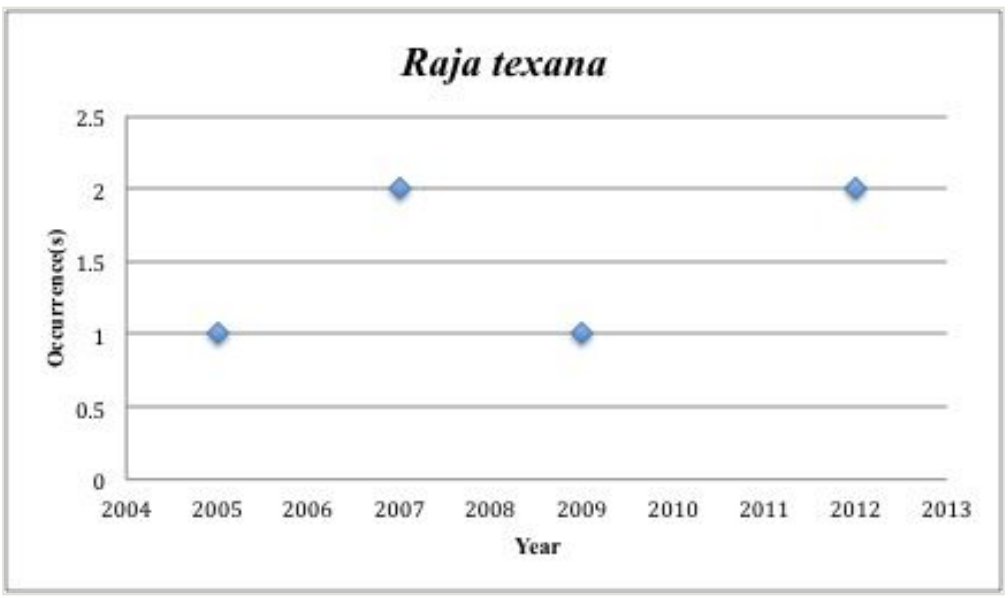

Figure 27.

Raja texana

71) Sanopus reticulates - Reticulate toadfish - Batrachoididae (Insufficient data). Resilience: Medium - last time collected: 1977 
72) Sphoeroides parvus - Least Puffer - Tetraodontidae (Insufficient data). Resilience: High (Fig. 28)

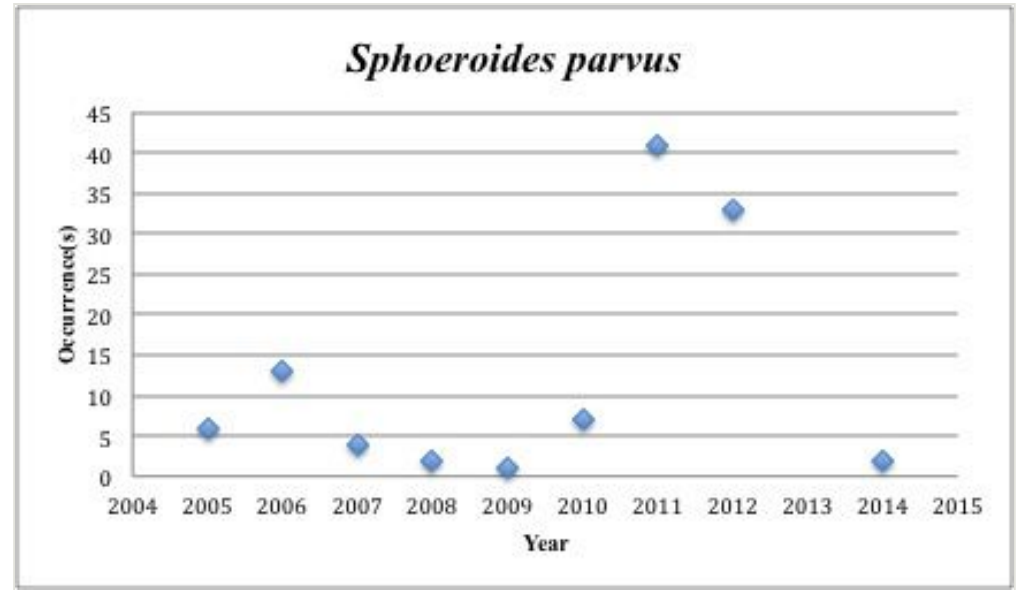

Figure 28.

Sphoeroides parvus

73) Sphoeroides spengleri - Bandtail Puffer - Tetraodontidae (.4\% range overlap with spill zone). Resilience: High (Fig. 29)

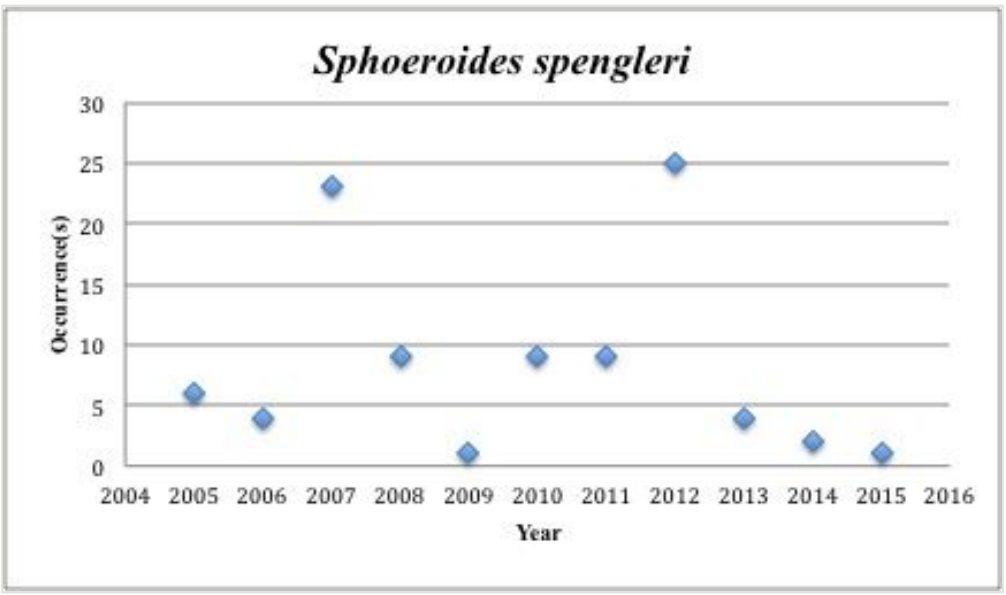

Figure 29.

Sphoeroides spengleri

74) Stemonosudis bullisi - Paralepididae (Insufficient data). Resilience: High - last time collected: 1960 
75) Syngnathus affinis - Texas Pipefish - Syngnathidae (No range overlap with spill zone).

Resilience: High - last time collected: 1983

76) Trichopsetta ventralis - Sash Flounder - Bothidae (31\% range overlap with spill zone). Resilience: Medium (Fig. 30)

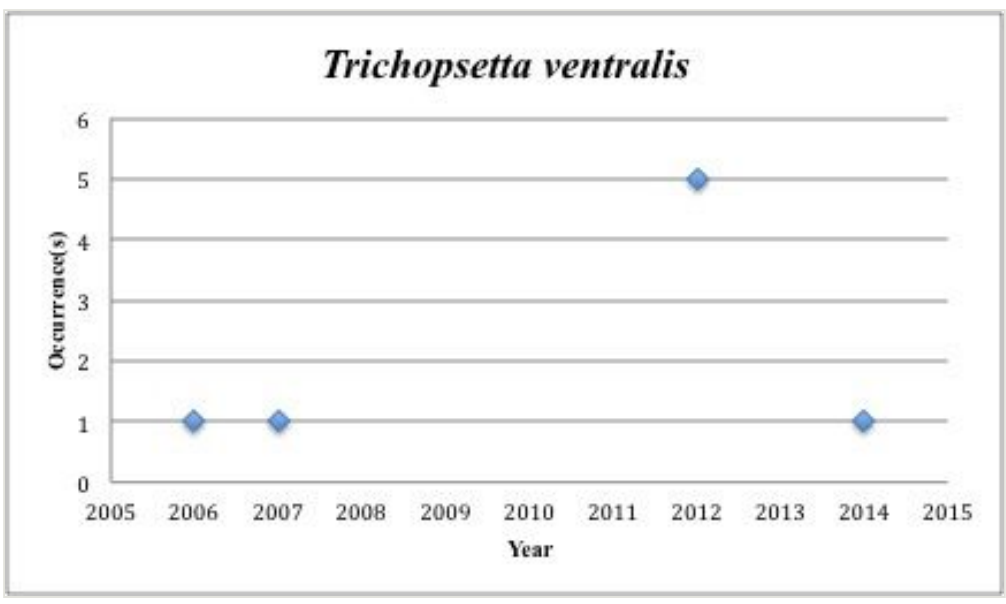

Figure 30.

Trichopsetta ventralis

77) Varicus marilynae - Orangebelly Goby - Gobiidae (No range overlap with spill zone). Resilience: High - last time observed: 1974

\section{Discussion}

The continued influence of an oil spill that occurred more than five years ago on the Gulf of Mexico is evident (Incardona et al. 2014; Alloy et al. 2016; Schaefer et al. 2015); however, data about population status, or even tangible proof of the continued existence of many of the Gulf's endemic fish species, is lacking. More than half (45) of the 77 endemic species from the Gulf of Mexico have not been officially collected since the 2010 spill. Of these, nine species have not been collected since before 1980, eight species have not been collected since the 1980s, and two not since the 1990s. Although there is a focus on fisheries data for commercially important species post-spill, the endemic species examined here are among the Gulf species we know the least about. Even with the data presented here our study of collections records must be viewed as a small glimpse into the true effects of the spill. Collections records are not a true estimate of population dynamics; however, in the case of rare and poorly studied species (as is the case with these endemics) - it is our best estimate. 
The species we should perhaps be most concerned for are the 14 that have collection records in the five years before the spill, but lack records post-spill (2010-2015). Among these are Fundulus jenkinsi collected 306x, Menidia colei (29x), Jordanella pulchra (10x), Ogilbia cayorum (6x), and Etmopterus schultzi and Monopenchelys acuta both collected 5x. Gambusia yucatana was collected $14 \mathrm{x}$ in the last 10 years, and all but one of those was pre-spill.

Other species appear to be more common post-spill, with most of the collections occuring in the last five years (rather than the 2005-2010 period): Trichopsetta ventralis (6 of 8 collections post-2010), Sphoeroides parvus (83 of 109), Prionotus longispinous (203 of 206), Prionotus paralatus (74 of 76), Opsanus pardus (6 of 7), Ogcocephalus pantostictus (6 of 6), Gobiosoma longipala (2 of 2). It should be noted that all the collections of Halieutichthys intermedius are post-spill because this species was described in 2012 (Ho et al. 2012) and most museums have not updated their records for this species. Some of the species that had higher collections numbers post spill may have been influenced by the closing of fisheries during and after the immediate period of the oil spill (Schaefer et al. 2015). Although not directly targeted for fisheries these species may have increased in number because they were not collected as by-catch when fishing was closed. Also the increased interest in collecting and studying Gulf species post spill may have increased efforts to identify and catalogue these species. We also note here that the collections efforts pre- and post-spill were likely not equal. We therefore cannot do a statistical sampling comparison based on collecting effort.

There are some notable trends among and within groups as well. Of the six eels in the study (Elopomorpha Families: Ophichthidae, Muraenidae, Congridae) only one species, Ophichthus rex had a high percentage of its range in the region of the spill (82\%) and it has been collected once since the spill. However, eel species in general are very rare in collections, and little or no data about any of the endemic eels from the Gulf of Mexico is known (9 total collection records, all post spill).

Of the seven cartilaginous fishes (Elasmobranchii Families: Anacanthobatidae, Rajidae, Etmopteridae, Triakidae) most had a high proportion of their range in the area of the spill zone but most have post-spill collections. The exception being the rare Anacanthobatis folirostris, which has no collection records since 2004. These elasmobranchs all have low resiliency, with populations doubling time between 4.5-14 years (Froese and Pauly 2016). Most members of the small but diverse members of gobies (Gobioidei) and blennies (Blennioidei) lack sufficient information (in being collected mostly before 2005), as is the case for most of the ten coral associated endemic Gulf species (Table 1). Inshore brackish fishes such as those in the families Lepisosteidae, Clupeidae, Atherinopsidae, Fundulidae, Poeciliidae, and Cyprinodontidae, were mainly out of the area of the immediate spill (i.e., little overlap with the region of the spill as initially measured) and are among the most collected species among Gulf endemics (Table 1). However, although the collections may be high, the documented developmental impairment of near shore species points to the fact that even these species are not out of harms way (Dubansky et al. 2013). Additionally, 
the influence of the oil slick at the surface on pelagic larvae and in the deep-sea on individuals that are rarely seen will never be completely known (Fodrie and Heck 2011).

Table 1.

Summary of species occurrence records (based on GBIF and FishNET2), and habitat types (from McEachran 2009; Chakrabarty et al. 2012). Taxa that were deemed "Species of Greatest Concern" by Chakrabarty et al. (2012) are in bold. These species had $35 \%$ of their historical occurrence records in the region of the oil spill.

\begin{tabular}{|c|c|c|c|c|}
\hline $\begin{array}{l}\text { Species: } \\
\text { Scientific name }\end{array}$ & Family & $\begin{array}{l}\text { Occurrences: } \\
\text { 2010-present }\end{array}$ & $\begin{array}{l}\text { Occurrences: } \\
\text { 2005-present }\end{array}$ & Habitat \\
\hline Alosa alabamae & Clupeidae & 12 & 24 & $\begin{array}{l}\text { Bay and Near Shore, } \\
\text { Anadromous, Neritic }\end{array}$ \\
\hline Alosa chrysochloris & Clupeidae & 47 & 177 & $\begin{array}{l}\text { Bay and Near Shore, } \\
\text { Anadromous, Neritic }\end{array}$ \\
\hline $\begin{array}{l}\text { Anacanthobatis } \\
\text { folirostris }\end{array}$ & Anacanthobatidae & 0 & 0 & Slope \\
\hline Atherinella schultzi & Atherinopsidae & 1 & 1 & $\begin{array}{l}\text { Bay and Near Shore, } \\
\text { Estuarine }\end{array}$ \\
\hline Atractosteus spatula & Lepisosteidae & 15 & 29 & $\begin{array}{l}\text { Bay and Near Shore, } \\
\text { Neritic, Estuarine }\end{array}$ \\
\hline Bollmannia communis & Gobiidae & 4 & 5 & $\begin{array}{l}\text { Demersal, Soft } \\
\text { Substrates }\end{array}$ \\
\hline $\begin{array}{l}\text { Bollmannia } \\
\text { eigenmanni }\end{array}$ & Gobiidae & 0 & 0 & Demersal \\
\hline Brevoortia gunteri & Clupeidae & 9 & 17 & $\begin{array}{l}\text { Bay and Near Shore, } \\
\text { Neritic, Estuarine }\end{array}$ \\
\hline Brevoortia patronus & Clupeidae & 85 & 180 & $\begin{array}{l}\text { Bay and Near Shore, } \\
\text { Neritic, Estuarine }\end{array}$ \\
\hline Calamus arctifrons & Sparidae & 9 & 32 & Demersal, Seagrass \\
\hline Calamus campechanus & Sparidae & 0 & 0 & Demersal \\
\hline \multirow[t]{3}{*}{ Chasmodes longimaxilla } & Blenniidae & 0 & 0 & Demersal, Coral Reef \\
\hline & Gobiidae & 0 & 0 & Demersal \\
\hline & Gobiidae & 0 & 0 & Demersal \\
\hline Citharichthys abbotti & Paralichthyidae & 0 & 0 & $\begin{array}{l}\text { Demersal, Soft } \\
\text { Substrates }\end{array}$ \\
\hline $\begin{array}{l}\text { Coryphaenoides } \\
\text { mexicanus }\end{array}$ & Macrouridae & 2 & 2 & $\begin{array}{l}\text { Benthopelagic, Slope, } \\
\text { Abyssal }\end{array}$ \\
\hline $\begin{array}{l}\text { Coryphopterus } \\
\text { punctipectophorus }\end{array}$ & Gobiidae & 0 & 0 & Demersal, Coral Reef \\
\hline Ctenogobius claytonii & Gobiidae & 0 & 1 & $\begin{array}{l}\text { Demersal, Bay and Near } \\
\text { Shore, Estuarine }\end{array}$ \\
\hline
\end{tabular}




\begin{tabular}{|c|c|c|c|c|}
\hline Cynoscion arenarius & Sciaenidae & 33 & 90 & $\begin{array}{l}\text { Demersal, Beach and } \\
\text { Shoreline, Soft } \\
\text { Substrates }\end{array}$ \\
\hline \multirow[t]{2}{*}{ Dipturus olseni } & Rajidae & 0 & 2 & Demersal, Slope \\
\hline & Rajidae & 0 & 0 & Slope \\
\hline Eptatretus minor & Myxinidae & 0 & 2 & $\begin{array}{l}\text { Slope, Soft Substrates, } \\
\text { Burrower }\end{array}$ \\
\hline \multirow[t]{2}{*}{ Eptatretus springeri } & Myxinidae & 1 & 1 & $\begin{array}{l}\text { Slope, Soft Substrates, } \\
\text { Burrower }\end{array}$ \\
\hline & Etmopteridae & 0 & 5 & Slope \\
\hline Eustomias leptobolus & Stomiidae & 0 & 0 & Mesopelagic \\
\hline Exechodontes daidaleus & Zoarcidae & 0 & 0 & Benthic, Slope \\
\hline Floridichthys carpio & Cyprinodontidae & 3 & 17 & $\begin{array}{l}\text { Bay and Near Shore, } \\
\text { Estuarine, Seagrass }\end{array}$ \\
\hline Fundulus grandis & Fundulidae & 97 & 292 & $\begin{array}{l}\text { Bay and Near Shore, } \\
\text { Estuarine, Seagrass }\end{array}$ \\
\hline Fundulus jenkinsi & Fundulidae & 0 & 306 & $\begin{array}{l}\text { Bay and Near Shore, } \\
\text { Estuarine }\end{array}$ \\
\hline Fundulus persimilis & Fundulidae & 0 & 2 & $\begin{array}{l}\text { Bay and Near Shore, } \\
\text { Estuarine }\end{array}$ \\
\hline Fundulus pulvereus & Fundulidae & 35 & 69 & $\begin{array}{l}\text { Bay and Near Shore, } \\
\text { Estuarine }\end{array}$ \\
\hline Fundulus xenicus & Fundulidae & 20 & 92 & $\begin{array}{l}\text { Bay and Near Shore, } \\
\text { Estuarine }\end{array}$ \\
\hline Gambusia yucatana & Poeciliidae & 1 & 14 & $\begin{array}{l}\text { Bay and Near Shore, } \\
\text { Estuarine }\end{array}$ \\
\hline Gobiosoma longipala & Gobiidae & 2 & 2 & $\begin{array}{l}\text { Demersal, Soft } \\
\text { Substrates }\end{array}$ \\
\hline Gordiichthys ergodes & Ophichthidae & 0 & 3 & $\begin{array}{l}\text { Demersal, Burrower, Soft } \\
\text { Substrates }\end{array}$ \\
\hline Gordiichthys leibyi & Ophichthidae & 0 & 0 & $\begin{array}{l}\text { Demersal, Soft } \\
\text { Substrates, Burrower }\end{array}$ \\
\hline $\begin{array}{l}\text { Gunterichthys } \\
\text { longipenis }\end{array}$ & Bythitidae & 0 & 0 & $\begin{array}{l}\text { Demersal, Bay and } \\
\text { Near Shore, Burrower }\end{array}$ \\
\hline Gymnachirus texae & Achiridae & 1 & 1 & $\begin{array}{l}\text { Demersal, Soft } \\
\text { Substrates }\end{array}$ \\
\hline Halichoeres burekae & Labridae & 0 & 2 & Coral Reef \\
\hline $\begin{array}{l}\text { Halieutichthys } \\
\text { intermedius }\end{array}$ & Ogcocephalidae & 5 & 5 & $\begin{array}{l}\text { Benthic, Soft } \\
\text { Substrates }\end{array}$ \\
\hline Heteroconger luteolus & Congridae & 0 & 0 & Demersal \\
\hline Hyperoglyphe bythites & Centrolophidae & 0 & 1 & Benthopelagic \\
\hline $\begin{array}{l}\text { Hypleurochilus } \\
\text { caudovittatus }\end{array}$ & Blenniidae & 0 & 0 & $\begin{array}{l}\text { Demersal, Soft } \\
\text { Substrates }\end{array}$ \\
\hline
\end{tabular}




\begin{tabular}{|c|c|c|c|c|}
\hline Hypleurochilus multifilis & Blenniidae & 0 & 0 & Demersal, Coral Reef \\
\hline Ijimaia antillarum & Ateleopodidae & 0 & 0 & Benthic, Slope \\
\hline Jordanella floridae & Cyprinodontidae & 19 & 40 & $\begin{array}{l}\text { Bay and Near Shore, } \\
\text { Estuarine, Seagrass, }\end{array}$ \\
\hline Jordanella pulchra & Cyprinodontidae & 0 & 10 & $\begin{array}{l}\text { Bay and Near Shore, } \\
\text { Estuarine }\end{array}$ \\
\hline Lepisosteus oculatus & Lepisosteidae & 84 & 146 & $\begin{array}{l}\text { Neritic, Bay and Near } \\
\text { Shore, Estuarine }\end{array}$ \\
\hline Leucoraja lentiginosa & Rajidae & 1 & 1 & Demersal, Slope \\
\hline Lupinoblennius nicholsi & Blenniidae & 0 & 0 & Demersal \\
\hline Lycenchelys bullisi & Zoarcidae & 0 & 0 & Benthic, Slope \\
\hline Menidia clarkhubbsi & Atherinopsidae & 0 & 0 & $\begin{array}{l}\text { Bay and Near Shore, } \\
\text { Estuarine }\end{array}$ \\
\hline Menidia colei & Atherinopsidae & 0 & 29 & $\begin{array}{l}\text { Bay and Near Shore, } \\
\text { Estuarine }\end{array}$ \\
\hline Menidia conchorum & Atherinopsidae & 0 & 0 & $\begin{array}{l}\text { Bay and Near Shore, } \\
\text { Coral Reef }\end{array}$ \\
\hline $\begin{array}{l}\text { Microdesmus } \\
\text { lanceolatus }\end{array}$ & Microdesmidae & 0 & 0 & $\begin{array}{l}\text { Demersal, Bay and } \\
\text { Near Shore, Burrower }\end{array}$ \\
\hline Monopenchelys acuta & Muraenidae & 0 & 5 & Demersal, Coral Reef \\
\hline $\begin{array}{l}\text { Mustelus } \\
\text { sinusmexicanus }\end{array}$ & Triakidae & 2 & 0 & Soft Substrates \\
\hline $\begin{array}{l}\text { Neoopisthopterus } \\
\text { cubanus }\end{array}$ & Clupeidae & 0 & 0 & $\begin{array}{l}\text { Neritic, Bay and Near } \\
\text { Shore, Beach and } \\
\text { Shoreline, Estuarine }\end{array}$ \\
\hline $\begin{array}{l}\text { Ogcocephalus } \\
\text { pantostictus }\end{array}$ & Ogcocephalidae & 6 & 6 & Demersal \\
\hline Ogilbia cayorum & Bythitidae & 0 & 6 & $\begin{array}{l}\text { Demersal, Hard } \\
\text { Substrate }\end{array}$ \\
\hline Oneirodes bradburyae & Oneirodidae & 0 & 0 & Bathypelagic \\
\hline Ophichthus omorgmus & Ophichthidae & 0 & 0 & $\begin{array}{l}\text { Benthic, Slope, Soft } \\
\text { Substrates }\end{array}$ \\
\hline Ophichthus rex & Ophichthidae & 0 & 1 & $\begin{array}{l}\text { Demersal, Soft } \\
\text { Substrates, Burrower }\end{array}$ \\
\hline Opsanus pardus & Batrachoididae & 6 & 7 & $\begin{array}{l}\text { Demersal, Hard } \\
\text { Substrates }\end{array}$ \\
\hline $\begin{array}{l}\text { Parasaccogaster } \\
\text { rhamphidognatha }\end{array}$ & Bythitidae & 0 & 0 & $\begin{array}{l}\text { Benthic, Slope, Soft } \\
\text { Substrates }\end{array}$ \\
\hline $\begin{array}{l}\text { Parmaturus } \\
\text { campechiensis }\end{array}$ & Scyliorhinidae & 0 & 0 & Slope, Soft Substrates \\
\hline $\begin{array}{l}\text { Prionotus } \\
\text { longispinosus }\end{array}$ & Triglidae & 203 & 207 & $\begin{array}{l}\text { Demersal, Soft } \\
\text { Substrates }\end{array}$ \\
\hline Prionotus martis & Triglidae & 24 & 26 & Demersal \\
\hline
\end{tabular}




\begin{tabular}{|l|l|l|l|l|}
\hline Prionotus paralatus & Triglidae & 74 & 76 & $\begin{array}{l}\text { Demersal, Benthic, } \\
\text { Slope }\end{array}$ \\
\hline Raja texana & Rajidae & 2 & 6 & Demersal \\
\hline Sanopus reticulatus & Batrachoididae & 0 & 0 & $\begin{array}{l}\text { Coastal Surface and } \\
\text { Epipelagic, Demersal }\end{array}$ \\
\hline Sphoeroides parvus & Tetraodontidae & 83 & 109 & $\begin{array}{l}\text { Demersal, Bay and Near } \\
\text { Shore }\end{array}$ \\
\hline Sphoeroides spengleri & Tetraodontidae & 50 & 93 & $\begin{array}{l}\text { Demersal, Coral Reef, } \\
\text { Seagrass }\end{array}$ \\
\hline Stemonosudis bullisi & Paralepididae & 0 & 0 & Mesopelagic \\
\hline Syngnathus affinis & Syngnathidae & 0 & 0 & $\begin{array}{l}\text { Benthopelagic, Bay and } \\
\text { Near Shore, Seagrass }\end{array}$ \\
\hline Trichopsetta ventralis & Bothidae & 6 & 8 & $\begin{array}{l}\text { Demersal, Benthic, Soft } \\
\text { Substrates }\end{array}$ \\
\hline Varicus marilynae & Gobiidae & 0 & 0 & Demersal \\
\hline
\end{tabular}

More than quarter of the Gulf of Mexico endemic fish species (20) had greater than $35 \%$ of their historical records in the area of the spill zone (Chakrabarty et al. 2012; those in bold text in Table 1). These species were identified by Chakrabarty et al. (2012) as being in the highest potential impact category. Of these species half (10 species) still lack any collection records post spill. We note that both GBIF and FishNET are not perfect records of all collecting events or even all museum collections. Also we note that these databases are dynamic and change on a near daily basis as museum records are uploaded and updated. For that reason the data in this paper should be taken as a snapshot of the information available at this time. It is clear more work needs to be done to find and potentially protect these endemic taxa. Future work will include citizen science projects by the authors (see Acknowledgements) and others, that will target Gulf endemics and add data, museum records, and increase community awareness. We hope this study helps focus conservation efforts on those species that lack the most information, or that have not been collected post-spill.

\section{Acknowledgements}

We thank the National Academies Keck Futures Initiative for funding to BB and PC - Crude Life: A Citizen Art and Science Investigation of Gulf of Mexico Biodiversity after the Deepwater Horizon Oil Spill.

\section{References}

- $\quad$ Alloy M, Baxter D, Stieglitz J, Mager E, Hoenig R, Benetti D, Grosell M, Oris J, Roberts A (2016) Ultraviolet Radiation Enhances the Toxicity of Deepwater Horizon Oil to Mahimahi (Coryphaena hippurus) Embryos. Environmental Science \& Technology 50 (4): 2011-2017. DOI: 10.1021/acs.est.5b05356 
- $\quad$ Brette F, Machado B, Cros C, Incardona JP, Scholz NL, Block BA (2014) Crude Oil Impairs Cardiac Excitation-Contraction Coupling in Fish. Science 343 (6172): 772-776. DOI: $10.1126 /$ science. 1242747

- $\quad$ Chakrabarty P, Warren M, Page L, Baldwin C (2013) GenSeq: An updated nomenclature and ranking for genetic sequences from type and non-type sources. ZooKeys 346: 29-41. DOI: 10.3897/zookeys.346.5753

- Chakrabarty P, Lam C, Hardman J, Aaronson J, House P, Janies D (2012) SpeciesMap: a web-based application for visualizing the overlap of distributions and pollution events, with a list of fishes put at risk by the 2010 Gulf of Mexico oil spill. Biodiversity and Conservation 21 (7): 1865-1876. DOI: 10.1007/s10531-012-0284-4

- Crone TJ, Tolstoy M (2010) Magnitude of the 2010 Gulf of Mexico Oil Leak. Science 330 (6004): 634-634. DOI: $10.1126 /$ science.1195840

- Drew J (2011) The Role of Natural History Institutions and Bioinformatics in Conservation Biology. Conservation Biology 25 (6): 1250-1252. DOI: $10.1111 /$ j.1523-1739.2011.01725.x

- Dubansky B, Whitehead A, Miller J, Rice C, Galvez F (2013) Multitissue Molecular, Genomic, and Developmental Effects of the Deepwater Horizon Oil Spill on Resident Gulf Killifish (Fundulus grandis). Environmental Science \& Technology 47 (10): 5074-5082. DOI: $10.1021 /$ es400458p

- $\quad$ Fodrie FJ, Heck K (2011) Response of Coastal Fishes to the Gulf of Mexico Oil Disaster. PLoS ONE 6 (7): e21609. DOI: 10.1371/journal.pone.0021609

- Fodrie FJ, Able KW, Galvez F, Heck KL, Jensen OP, Lopez-Duarte PC, Martin CW, Turner RE, Whitehead A (2014) Integrating Organismal and Population Responses of Estuarine Fishes in Macondo Spill Research. BioScience 64 (9): 778-788. DOI: 10.109 3/biosci/biu123

- $\quad$ Froese R, Pauly D (2016) FishBase. FishBase 1: 1. URL: www.fishbase.org

- Goodbody-Gringley G, Wetzel D, Gillon D, Pulster E, Miller A, Ritchie K (2013) Toxicity of Deepwater Horizon Source Oil and the Chemical Dispersant, Corexit ${ }^{\circledR} 9500$, to Coral Larvae. PLoS ONE 8 (1): e45574. DOI: 10.1371/journal.pone.0045574

- Incardona JP, Gardner LD, Linbo TL, Brown TL, Esbaugh AJ, Mager EM, Stieglitz JD, French BL, Labenia JS, Laetz CA, Tagal M, Sloan CA, Elizur A, Benetti DD, Grosell M, Block BA, Scholz NL (2014) PNAS Plus: From the Cover: Deepwater Horizon crude oil impacts the developing hearts of large predatory pelagic fish. Proceedings of the National Academy of Sciences 111 (15): E1510-E1518. DOI: 10.1073/ pnas.1320950111

- $\quad$ Mager E, Esbaugh A, Stieglitz J, Hoenig R, Bodinier C, Incardona J, Scholz N, Benetti D, Grosell M (2014) Acute Embryonic or Juvenile Exposure to Deepwater Horizon Crude Oil Impairs the Swimming Performance of Mahi-Mahi (Coryphaena hippurus). Environmental Science \& Technology 48 (12): 7053-7061. DOI: 10.1021/es501628k

- Rabalais N (2014) Assessing Early Looks at Biological Responses to the Macondo Event. BioScience 64 (9): 757-759. DOI: 10.1093/biosci/biu132

- Rocha LA, Aleixo A, Allen G, Almeda F, Baldwin CC, Barclay MVL, Bates JM, Bauer AM, Benzoni F, Berns CM, Berumen ML, Blackburn DC, Blum S, Bolanos F, Bowie RCK, Britz R, Brown RM, Cadena CD, Carpenter K, Ceriaco LM, Chakrabarty P, Chaves G, Choat JH, Clements KD, Collette BB, Collins A, Coyne J, Cracraft J, Daniel T, de Carvalho M, Queiroz Kd, Dario FD, Drewes R, Dumbacher JP, Engilis A, Erdmann MV, Eschmeyer W, Feldman CR, Fisher BL, Fjeldsa J, Fritsch PW, Fuchs J, Getahun A, 
Gill A, Gomon M, Gosliner T, Graves GR, Griswold CE, Guralnick R, Hartel K, Helgen $\mathrm{KM}$, Ho H, Iskandar DT, Iwamoto T, Jaafar Z, James HF, Johnson D, Kavanaugh D, Knowlton N, Lacey E, Larson HK, Last P, Leis JM, Lessios H, Liebherr J, Lowman M, Mahler DL, Mamonekene V, Matsuura K, Mayer GC, Mays H, McCosker J, McDiarmid RW, McGuire J, Miller MJ, Mooi R, Mooi RD, Moritz C, Myers P, Nachman MW, Nussbaum RA, Foighil DO, Parenti LR, Parham JF, Paul E, Paulay G, Perez-Eman J, Perez-Matus A, Poe S, Pogonoski J, Rabosky DL, Randall JE, Reimer JD, Robertson DR, Rodel M-O, Rodrigues MT, Roopnarine P, Ruber L, Ryan MJ, Sheldon F, Shinohara G, Short A, Simison WB, Smith-Vaniz WF, Springer VG, Stiassny M, Tello JG, Thompson CW, Trnski T, Tucker P, Valqui T, Vecchione M, Verheyen E, Wainwright PC, Wheeler TA, White WT, Will K, Williams JT, Williams G, Wilson EO, Winker K, Winterbottom R, Witt CC (2014) Specimen collection: An essential tool. Science 344 (6186): 814-815. DOI: 10.1126/science.344.6186.814

- Schaefer J, Frazier N, Barr J (2015) Dynamics of Near-Coastal Fish Assemblages following the Deepwater Horizon Oil Spill in the Northern Gulf of Mexico. Transactions of the American Fisheries Society 145 (1): 108-119.

DOI: $10.1080 / 00028487.2015 .1111253$

- Whitehead A, Dubansky B, Bodinier C, Garcia TI, Miles S, Pilley C, Raghunathan V, Roach JL, Walker N, Walter RB, Rice CD, Galvez F (2011) Genomic and physiological footprint of the Deepwater Horizon oil spill on resident marsh fishes. Proceedings of the National Academy of Sciences 109 (50): 20298-20302. DOI: 10.1073/pnas.1109545108 